shows that it is still active and growing in membership ("The Men of the Trees." Ninth Year's Report and Review of the Tree Year 1933. Pp. $36+4$ plates. London : Hon. Secretary, 32 Warwick Road, S.W.5. 6d.). Whilst the death duties cause the break up of many old well-wooded estates and realisation upon their timber, the Forestry Commission still suffers under a cut of $£ 400,000$, so that its planting programme is inevitably cut down. Under these conditions, there is ample room for the activities of this society, which in its ninth annual report gives an extensive account of an important statement upon the position of forestry in the Empire made at the annual meeting of the society by Prof. Troup, of the Imperial Forestry Institute, Oxford.

\section{Works on Astrology and Alchemy}

AN interesting catalogue of second-hand books on astronomy, astrology, alchemy and the occult sciences has recently been published by Emile Offenbacher, 10 Rue Pasquier, Paris, 8e. Among the more attractive items may be noted the first Italian edition of Euclid, with a commentary by Tartaglia (1543), a first edition of Galileo's "Istoria e dimostrazione intorno alle macchie solari" (1613), a second edition of Reisch's "Margarita philosophica" (1504), a copy of Thomas Radini's "Sideralis abyssus" (1511), and the first edition of Kertzen. macher's "Alchimia" (1538). A score of books on the Rosy Cross are included, and all the items appear to be very moderately priced. Bibliographical notes are given in sufficient detail, a feature which, with the numerous illustrations, will make the catalogue a useful book of reference even when the books it describes have found scattered homes in the libraries of collectors. We hope that M. Offenbacher will give us further catalogues of the same kind, for they represent a real contribution to the history of science.

\section{Announcements}

The Albert Medal of the Royal Society of Arts for 1934 has been awarded to Sir Frederick Gowland Hopkins, president of the Royal Society, for his researches in biochemistry and the constituents of foods. The medal is awarded annually "for distinguished merit in promoting arts, manufactures, or commerce".

Prof. A. C. Seward, professor of botany in the University of Cambridge, has been elected a foreign member of the Botany Class of the Royal Swedish Academy of Sciences.

Sir Frederick Gowland Hopkins will unveil a plaque to William Hyde Wollaston at 14 Buckingham Street, W.1, on Wednesday, July 4, at 3.30 p.m.

Prof. P. L. Mercanton, professor of meteorology and geophysics in the University of Lausanne, has been appointed director of the Central Meteorological Station of the Commission federale suisse de Meteorologie, in succession to Dr. J. Maurer, who has recently retired.

THE following appointments in the Colonial agricultural service have been made by the Secretary of State for the Colonies: Mr. A. K. Briant, to be agricultural superintendent, St. Vincent; Mr. M. Halcrow, to be agricultural officer, Kenya; Mr. N. M. Wight, to be district agricultural officer, Tanganyika; Mr. H. W. Jack (economic botanist, Federated Malay States), to be director of agriculture, Fiji ; Mr. F. L. Squibbs (assistant agricultural officer, Dominica), to be director of agriculture, Seychelles.

IT is announced in the Times of June 9 that the Belgian National Scientific Research Fund has made a grant of 750,000 francs (more than $£ 7,100$ ) for the erection in Brussels of the Albert Library in memory of the late King of the Belgians. The Société Financière Mutuelle Solvay has subseribed 500,000 francs.

ADVISORY leaflets on matters of interest to farmers, recently issued by the Ministry of Agriculture and Fisheries, include one on the use of seaweed as manure, pointing out its special value for crops which require a large amount of potash and are benefited by salt. Other leaflets deal with birds of agricultural significance (more or less); they include the kestrel, landrail and nightjar. Another describes the activities, life-history and control of the turnip gall weevil.

Applications are invited for the following appointments, on or before the dates mentioned :-A principal of the Municipal Technical College, Halifax-The Education Officer, Education Offices, West House, Halifax (June 18). An assistant master to teach surveying and general science at the Pontardawe Mining and Technical Institute-The Director of Education, County Hall, Cardiff (June 18). A teacher of botany and chemistry at the Ashford and Folkestone Technical Institutes-The Principal, Technical Institute, Ashford (June 22). A lecturer in chemistry at Chesterfield Technical College-The Clerk to the Governors, Technical College, Infirmary Road, Chesterfield (June 23). A City electrical engineer for Plymouth-The Town Clerk, Municipal Buildings, Plymouth (June 25). A mining instructor at the County Secondary School and Cumberland Technical College, Workington-The Principal (June 23). A teacher of general chemistry at the Northern Polytechnic, Holloway, London, N.7-The Clerk (June 27). A veterinary officer to the County Borough of Wallasey-The Town Clerk, Town Hall, Wallasey (June 28). A junior lecturer in electrical engineering at the Military College of Science, Red Barracks, Woolwich, S.E.18-The Commandant (June 30). A district agricultural organiser for the East Anglian Institute of Agriculture, Chelmsford-The Clerk of the Council, County Hall, Chelmsford (July 2). An assistant lecturer in anatomy and an assistant lecturer in physiology at the University College of South Wales and Monmouthshire, Cardiff-The Registrar (July 7). A teacher of domestic science at the Princess Mary's Village Homes (Home Office 'Approved' School), Addlestone, Surrey-The Secretary. An assistant lecturer in mathematics at University College, Hull-The Registrar. A second assistant port engineer to the Basrah Port Directorate, Iraq-The Crown Agents for the Colonies, 4, Millbank, London, S.W.1. 